\title{
Incorporation of Crop Residues into Soil: A Practice to Improve Soil Chemical Properties
}

\author{
Sifolo S. Coulibaly ${ }^{*}$, Mamadou Touré2, Amoin E. Kouamé1, Ini C. Kambou1, Sientchon Y. Soro', \\ Kadokan I. Yéo ${ }^{2}$, Sita Koné1 \\ ${ }^{1}$ Department of Biological Sciences, University Peleforo Gon Coulibaly of Korhogo, Korhogo, Côte d'Ivoire \\ ${ }^{2}$ Laboratory of Ecology and Sustainable Development, University of Nangui Abrogoua, Abidjan, Côte d'Ivoire \\ Email: *coulsifsey@gmail.com
}

How to cite this paper: Coulibaly, S.S., Touré, M., Kouamé, A.E., Kambou, I.C., Soro, S.Y., Yéo, K.I. and Koné, S. (2020) Incorporation of Crop Residues into Soil: A Practice to Improve Soil Chemical Properties. Agricultural Sciences, 11, 1186-1198. https://doi.org/10.4236/as.2020.1112078

Received: October 3, 2020

Accepted: December 20, 2020

Published: December 23, 2020

Copyright $\odot 2020$ by author(s) and Scientific Research Publishing Inc. This work is licensed under the Creative Commons Attribution-NonCommercial International License (CC BY-NC 4.0). http://creativecommons.org/licenses/by-nc/4.0/ (c) (i) (8) Open Access

\begin{abstract}
Crop residues have the potential to enhance soil fertility, but this is dependent on their biochemical properties. This study aimed to evaluate the chemical composition, and nutrients release patterns of selected crop residues (corn stalk, rice straw, millet straw and sorghum stalk). Thus, $20 \mathrm{~g}$ of each crop residue were put in litter bags and placed in a plastic pot containing $10 \mathrm{~kg}$ of soil with a moisture content of $40 \%-60 \%$. Five replications were considered per type of residue and some samples were taken every 4 weeks. Results showed that crop residues got a $\mathrm{pH}$ varying between 5.09 and 6.5. The lowest $C$ content $(33.11 \%)$ and nitrogen $(0.27 \%)$ were measured in sorghum stalk when the highest $C$ content (47.6\%) and nitrogen content $(0.55 \%)$ were registered in corn stalk. The highest phosphorus content $(0.58 \%)$ was got in corn stalk. Potassium content was higher in millet straw than in others. The highest calcium content $(0.37 \%)$ and magnesium $(0.29 \%)$ were found in rice straw. There was an increase of soil chemical composition after crop residues burial. Significant increase in carbon, nitrogen, and phosphorus content was noted in soil at week 4 with the highest at week 16. At the end of the experiment, the highest $\mathrm{C}$ content $(53.1 \%)$ and the highest nitrogen content $(0.88 \%)$ in the soil were observed after burial of rice straw. The highest phosphorus content $(0.82 \%)$ registered in the soil was got with millet straw. Nutrient release efficiency of crop residues occurred in the following order: rice straw $>$ millet straw $>$ sorghum stalk $>$ corn stalk. This study has demonstrated that rice straw and millet straw released nutrients faster and this is beneficial for early planted crops, while sorghum stalk and corn stalk released nutrients slowly which is appropriate for long-term availability of plant nutrients.
\end{abstract}




\section{Keywords}

Crop Residues, Burial, Nutrient Release

\section{Introduction}

In tropical countries, the problems of physical degradation of cultivated soils are alarming. Indeed, accentuated by climatic disturbances [1], erosion is more and more aggressive and rapid, thus causing the establishment of ravines, the uprooting of trees, the fall of crops, the leaching of soils, the deregulation of seeds germination, etc. The degradation of the physical structure of soils is also due to intensive agriculture, uncontrolled logging, population growth, urbanization and industrialization [2]. In Côte d'Ivoire, more than 75\% of the forest area has disappeared in 30 years [3]. The conversion rate of natural habitats to agricultural lands was 43.3\% between 1986 and 2015 and still continues [4]. Primary forests represent only a small part of the forested area $(625,000$ ha or $6 \%)$, the vast majority of which now consists of modified natural forests (9.4 million ha, or 91\%) [5] [6]. However, farmers want to sustain their crop yields that push them to always pursue new and more fertile forest plots. Despite this notable increase in cultivated areas, there is still a decline in agricultural productivity due in large part to the deterioration of the physical, chemical and biological qualities of soils. This deterioration cannot be halted by chemical inputs utilization for financial, technical and environmental reasons [5]. In fact, intensive use of chemical fertilizers at the expense of organic inputs certainly increases immediately yields, but gradually destroys the soil (acidification of the environment, loss of mineral elements, release of heavy metals) [7]. In addition, these fertilizers are now increasingly expensive for small farmers with limited financial resources.

To cope with the physical degradation of soils, improvement of their structural stability through increasing soil organic matter content should be considered. This solution is the most relevant as organic matter is known to have an important role in the regeneration and stabilization of poor soil structure [8]. According to FAO [5], crop residues can be valuable resources for agriculture in developing countries. The use of crop wastes in agriculture is not only linked to their richness in nutrients but also to their ability to limit soil runoff and erosion and to increase water retention necessary for the development of plants and microorganisms [9]. The return of crop wastes to the soil is the main component that results in accumulation of nutrients, increases in organic matter and improvement of soil structure [10]. Incorporation of crop wastes into soil has the potential to provide a balanced supply of plant nutrients for crops [11] [12]. According to Scagnozzi [13] and Bauder [14], crop residues added to the soil decompose and can release significant levels of nutrients such as $\mathrm{N}, \mathrm{P}$ and $\mathrm{K}$.

In Côte d'Ivoire, precisely in the north, cereal crops (rice, corn, sorghum, mil- 
let) are grown over large areas, thus producing enormous quantities of residues. Unfortunately, these wastes are generally neglected in farming programs due to the existence of inadequate information regarding the value of a lot of organic wastes as sources of plant nutrients for crop production. In fact, crop wastes are generally stocked outside the farms and may provide a refuge for disease spores and pests that attack plants resulting in low yields [15]. Moreover, crop wastes are burned in situ on the fields [16] and the ash is blown away by the wind or washed by the rain when the ash contained nutrients that could fertilize the soil and consequently reduce soil acidity. It is therefore timely to evaluate the agronomic potential of crop residues, particularly cereal residues available in large quantities, before recommending their use as fertilizer to producers.

This study aimed to improve soil chemical composition through incorporation of cereal residues into soil after crops harvest. We hypothesized that cereal crop residues improve soil chemical properties when decomposing.

\section{Material and Methods}

\subsection{Study Site}

This study was conducted at the University Peleforo Gon Coulibaly, Korhogo (Côte d'Ivoire). Korhogo is located between latitudes $9^{\circ} 27 \mathrm{~N}-9^{\circ} 28 \mathrm{~N}$ and between longitudes $5^{\circ} 37 \mathrm{~W}-5^{\circ} 46 \mathrm{~W}$ at $360 \mathrm{~m}$ above sea level. The site experiences an average annual minimum temperature of $24.6^{\circ} \mathrm{C}$ and a maximum temperature of $28.9^{\circ} \mathrm{C}$. It receives an average annual rainfall of $1286 \mathrm{~mm}$ with a bimodal distribution. The relative humidity ranges between $72 \%$ and $86 \%$. The months of July, August and September receive the highest precipitations and the months of November to March are the driest.

\subsection{Treatments and Experimental Design}

The crop residues used in this study were the straw of rice, millet, and the stalks of corn and sorghum. These wastes were collected randomly in farms and were air dried. They were crushed into small particles with a blender and $20 \mathrm{~g}$ of each crop residue was put in litter bags measuring $20 \mathrm{~cm} \times 20 \mathrm{~cm}$ with $0.30 \mathrm{~mm}$ mesh. Five litter bags were retained per type of residue either a total number of 20 bags for the four types of wastes. Each litter bag containing crop residue was placed in a plastic pot, with a perforated base measuring $30 \mathrm{~cm}$ diameter and a height of $25 \mathrm{~cm}$, filled with $10 \mathrm{~kg}$ of soil. The litter bags were placed vertically at $5 \mathrm{~cm}$ under the surface of the soil. A basin was placed underneath each pot and water level was maintained at $2-3 \mathrm{~cm}$ depth. The content of the pots was initially moistened with water and the moisture content was maintained between $40 \%-60 \%$ to allow the survival of soil microorganisms responsible of the residue's decomposition [17]. The crop residues were incubated for four months. Five litter bags containing each crop residue were removed from each pot at a four-week interval. Then a sample of soil was taken from each pot and oven 
dried at $60^{\circ} \mathrm{C}$ to constant weight and put in well labeled bags for laboratory analysis. This method was based on that of Fosu et al. [18]. The experiment took place in a room at a temperature of $30^{\circ} \mathrm{C} \pm 1^{\circ} \mathrm{C}$ with an average relative humidity of $87.7 \%$.

The residues of crops and the samples taken during the experiment were analyzed to evaluate the variation of nutrients during the decomposition at the Laboratory of Chemical Analysis of National Petroleum Operations Company of Côte d'Ivoire. Total organic carbon (TOC) and total nitrogen (TN) were performed using a TRUSPEC-CHN ${ }^{\circledR}$ (LECO, US) elemental analyzer [19]. Deionized water suspension of each waste was used to measure the $\mathrm{pH}$ after mechanically agitation for $30 \mathrm{~min}$ and filtration with a sieve. Calcium $(\mathrm{Ca})$, magnesium $(\mathrm{Mg})$, potassium $(\mathrm{K})$ and phosphorus $(\mathrm{P})$ were determined by means of atomic absorption spectrophotometer (AA-220 FS) after digestion of the samples with concentrated HNO3: concentrated $\mathrm{HClO} 4(4: 1, \mathrm{v} / \mathrm{v})$.

\subsection{Data Analysis}

Collected data were subjected to analysis of variance (ANOVA) using SPSS package, Version 16. The means were compared using the least significant difference (LSD) test at $\mathrm{p} \leq 0.05$. The principle component analysis was performed to determine the relationship between the different crop residues, and their nutrients content.

\section{Results and Discussion}

\subsection{Initial Chemical Characteristics of Cereal Residues}

The initial chemical properties of the substrate (soil) and the residues of rice, corn, millet, and sorghum are recorded in Table 1. One-way analysis of variance (ANOVA I) showed that the chemical characteristics differed significantly from one type of residue to another. Regarding the $\mathrm{pH}$, it was acidic for the substrate and for all the crop residues. The lowest $\mathrm{pH}$ (5.09) was measured in the substrate and the highest (6.5) was registered in rice straw. According to the LSD test,

Table 1. Chemical characteristics of substrate and cereal residues. C: carbon, N: nitrogen, C/N: ratio carbon-nitrogen, C/P: ratio carbon-phosphorus, $\mathbf{P}$ : phosphorus, $\mathrm{K}$ : potassium, $\mathrm{Ca}$ : calcium, $\mathrm{Mg}$ : magnesium.

\begin{tabular}{|c|c|c|c|c|c|c|c|c|c|}
\hline \multirow{2}{*}{$\begin{array}{l}\text { Substrate } \\
\text { and cereal } \\
\text { residues }\end{array}$} & \multicolumn{9}{|c|}{ Nutriments (\%) } \\
\hline & $\mathrm{pH}$ & $\mathrm{C}(\%)$ & $\mathrm{N}(\%)$ & $\mathrm{C} / \mathrm{N}$ & $\mathrm{P}(\%)$ & $\mathrm{C} / \mathrm{P}$ & $\mathrm{K}(\%)$ & $\mathrm{Ca}(\%)$ & $\mathrm{Mg}(\%)$ \\
\hline Soil & $5.09 \pm 1.02^{c}$ & $1.46 \pm 0.01^{\mathrm{d}}$ & $0.12 \pm 0.01^{\mathrm{e}}$ & $12.18 \pm 1.31^{\mathrm{e}}$ & $0.03 \pm 0.00^{\mathrm{d}}$ & $48.67 \pm 2.83^{\mathrm{e}}$ & $0.67 \pm 0.00^{\mathrm{a}}$ & $0.23 \pm 0.001^{c}$ & $0.09 \pm 0.00^{c}$ \\
\hline Corn stalks & $6.3 \pm 1.25^{\mathrm{a}}$ & $47.6 \pm 13.17^{\mathrm{a}}$ & $0.55 \pm 0.01^{b}$ & $85.87 \pm 9.64^{\mathrm{cd}}$ & $0.58 \pm 0.04^{\mathrm{a}}$ & $82.06 \pm 21.03^{\mathrm{d}}$ & $0.29 \pm 0.03^{c}$ & $0.13 \pm 0.01^{\mathrm{d}}$ & $0.19 \pm 0.01^{\mathrm{b}}$ \\
\hline Millet straw & $6.2 \pm 1.13^{\mathrm{a}}$ & $35.27 \pm 8.69^{c}$ & $0.34 \pm 0.01^{\mathrm{d}}$ & $101.33 \pm 31.54^{\mathrm{b}}$ & $0.3 \pm 0.01^{\mathrm{c}}$ & $117.56 \pm 43.17^{\mathrm{c}}$ & $0.34 \pm 0.04^{c}$ & $0.23 \pm 0.01^{\mathrm{c}}$ & $0.28 \pm 0.01^{\mathrm{a}}$ \\
\hline Rice straw & $6.5 \pm 1.34^{\mathrm{a}}$ & $40.13 \pm 9.94^{\mathrm{b}}$ & $0.45 \pm 0.01^{\mathrm{c}}$ & $89.16 \pm 26.47^{c}$ & $0.31 \pm 0.01^{\mathrm{c}}$ & $129.45 \pm 51.12^{\mathrm{b}}$ & $0.21 \pm 0.06^{\mathrm{d}}$ & $0.37 \pm 0.01^{\mathrm{b}}$ & $0.29 \pm 0.03^{\mathrm{a}}$ \\
\hline $\begin{array}{l}\text { Sorghum } \\
\text { stalks }\end{array}$ & $6.2 \pm 1.21^{\mathrm{a}}$ & $33.11 \pm 11.10^{c}$ & $0.27 \pm 00^{\mathrm{e}}$ & $122.62 \pm 51.42^{\mathrm{a}}$ & $0.42 \pm 0.01^{\mathrm{b}}$ & $78.83 \pm 19.68^{\mathrm{d}}$ & $0.31 \pm 0.01^{\mathrm{c}}$ & $0.22 \pm 0.02^{\mathrm{c}}$ & $0.25 \pm 0.01^{\mathrm{a}}$ \\
\hline
\end{tabular}

Values followed by the same letter in a column are not significantly different $(\mathrm{p}>0.05)$ using LSD. 
there was no significant difference $(\mathrm{p}>0.05)$ between the $\mathrm{pH}$ of corn, millet, rice and sorghum residues. The acidic of the soil and the cereal crop residues could be linked to the growing conditions. In fact, producers used chemical minerals to improve their productivity and those fertilizers accumulated over past years might cause the acidity of the soil. According to Xie et al. [20], application of chemical fertilizers on soil provoked its acidity. Evidently, crops grown on acidic soil may have acidic $\mathrm{pH}$. The highest content of carbon $(47.6 \% \pm 13.17 \%)$, nitrogen $(0.55 \% \pm 0.01 \%)$, phosphorus $(0.58 \% \pm 0.04 \%)$ were registered in corn stalks. Relatively to the content of potassium, it ranged from $0.21 \% \pm 0.06 \%$ to $0.67 \% \pm 0.00 \%$ and those of calcium and magnesium varied respectively from $0.13 \% \pm 0.01 \%$ to $0.37 \% \pm 0.01 \%$ and from $0.09 \% \pm 0.00 \%$ to $0.29 \% \pm 0.03 \%$. $\mathrm{C} / \mathrm{N}$ ratio oscillated between $12.18 \pm 1.31$ and $122.62 \pm 51.42$ when $\mathrm{C} / \mathrm{P}$ ratio fluctuated from $48.67 \pm 2.83$ to $129.45 \pm 51.12$. These results attest to the nutrient richness of crop residues and they could be used to fertilize soil. In fact, crop residues are important natural resources, and their effective recycling improves the soil physical, chemical and biological properties. Similar results were obtained by Anguria et al. [21] in northeastern Uganda. Indeed, these authors observed high levels of nitrogen, phosphorus, and potassium in millet, sorghum, cowpea and peanut residues. The variation of nutrients in cereal crop residues could be justified by the soil they were grown on. The P contents in this study were higher than the critical limits $(0.12 \%-0.19 \%)$ defined for crop residues to pass from the state of immobilization to mineralization [22] and would result in rapid mineralization of residues by microorganisms. Thus, the different crop residues in this study will tend to decompose rapidly as their phosphorus contents are above the critical limits. According to Cattanio et al. [23], a low P content slows the rate of substrate decomposition due to nutrient immobilization. Baggie et al. [24] and Fosu et al. [18] indicated that crop residues with low biochemical composition tend to decompose slowly due to immobilization of nutrients.

\subsection{Variation of Chemical Characteristics of Substrate during Crop Wastes Decomposition}

\subsection{1. $\mathrm{pH}$}

The variations in the $\mathrm{pH}$ of the different crop residues during decomposition are shown on Figure 1. It appeared from the analysis that during the decomposition of the different residues, the $\mathrm{pH}$ of the substrate increased slightly. The $\mathrm{pH}$ of the substrate varied from 5.09 to 6 with corn residues, from 5.09 to 5.8 with millet straw, from 5.09 to 5.9 with sorghum residues and from 5.09 to 5.7 with rice straw. The increase in $\mathrm{pH}$ during the experiment might be linked to excess cations which indicate the concentration of organic anions within the materials. Increase in $\mathrm{pH}$ via the $\mathrm{C}$ cycle occur through $\mathrm{H}^{+}$association with organic compounds and the decarboxylation of organic anions in the residue [25]. Theoretically, $\mathrm{H}^{+}$association will occur if the $\mathrm{pKa}$ of the acid groups of the organic compounds is greater than the soil $\mathrm{pH}$ [26]. Through the $\mathrm{N}$ cycle, ammonification of organic $\mathrm{N}$ and nitrate uptake increase $\mathrm{pH}$ whereas nitrification and ammonium 


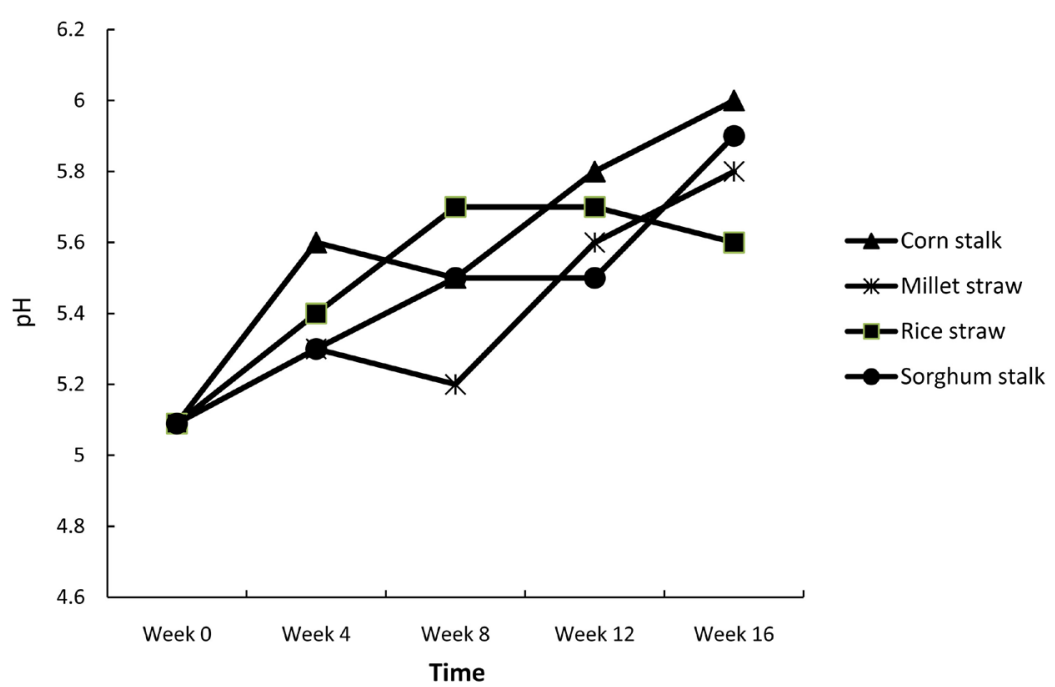

Figure 1. Variation of $\mathrm{pH}$ of substrate in function of time during crop residues decomposition.

uptake decrease $\mathrm{pH}$ [27]. Several laboratory incubations studies have shown that plant material increases pH [26] [28] [29] [30] [31]. However, the effect of residues on $\mathrm{pH}$ change varies widely between studies due to differences in residue composition and soils used. In particular, the initial $\mathrm{pH}$ of the soil is important for the $\mathrm{pH}$ change [25].

\subsubsection{Carbon, Nitrogen and Phosphorus}

The variation of carbon, nitrogen and phosphorus during the decomposition of the cereal crop residues are illustrated in Figure 2.

Soil organic carbon is the most important indicator of soil quality and agricultural sustainability. In this study, carbon content was $1.46 \%$ in the substrate at the start of the experiment. A month later, it increased to $10.7 \%, 16.5 \%, 13.2 \%$ and $15.2 \%$ respectively with corn stalk, millet straw, rice straw and sorghum stalk. After 8, 12 and 16 weeks of decomposition, the carbon content passed respectively to $23.4 \%, 36 \%$, and $40.2 \%$ with corn stalk. At weeks 8,12 and 16 respectively, carbon content was $30.1 \%, 44.6 \%$ and $50.8 \%$ in substrate with millet straw and $37.6 \%, 49.3 \%$ and $53.1 \%$ with rice straw. With sorghum stalk, carbon content was $23.4 \%, 38.7 \%$ and $41.7 \%$ respectively after 2,3 and 4 months of decomposition.

Relatively to nitrogen content, it increased significantly during residues decomposition. Nitrogen content after 4 months of decomposition was 4.25, 5.25, 6.33 and 4.58 times higher than the initial content when adding corn stalk, millet straw, rice straw and sorghum stalk respectively to the substrate.

Phosphorus content in the substrate varied significantly in function of time and type of waste during the decomposition of residues. The content of phosphorus in substrate ranged from $0.03 \%$ to $0.82 \%$ with corn stalk and from $0.03 \%$ to $0.72 \%$ with millet straw. In both cases, the highest phosphorus content was obtained at the end of the experiment. Statistical analysis showed that there was 


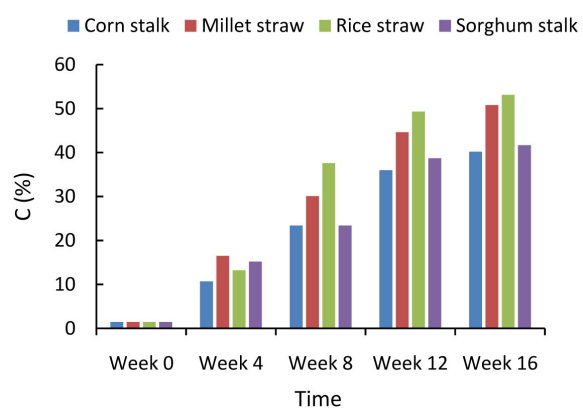

(a)

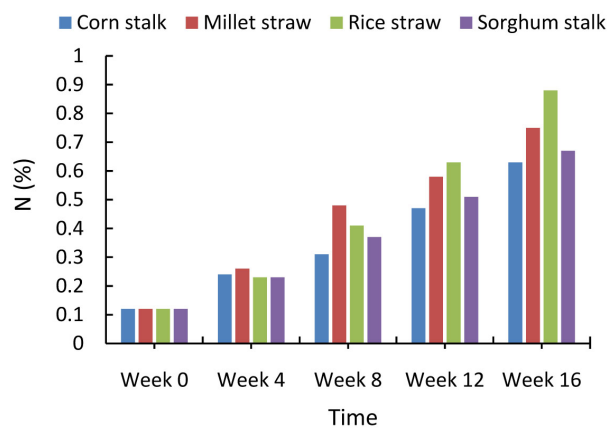

(b)

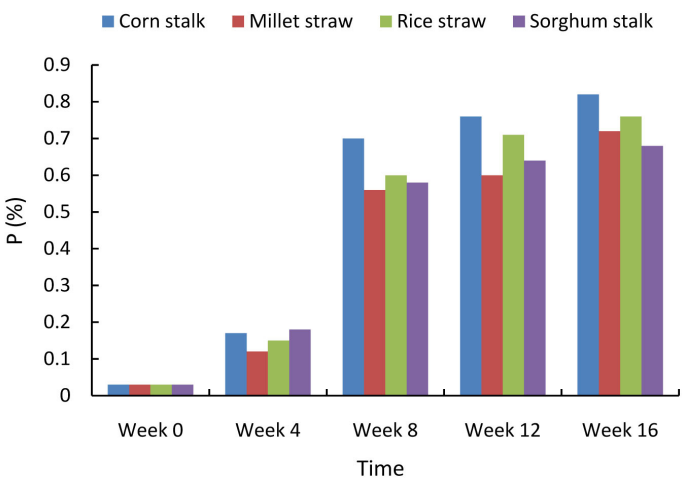

(c)

Figure 2. Variation of nutrients during decomposition of cereal residues. (a) C\%; (b) $\mathrm{N}$ (\%); (c) P (\%).

no significant difference $(\mathrm{p}>0.05$ ) between the phosphorus content measured at week 8 and at week 12 when using corn stalk or millet straw. During the decomposition of rice straw and sorghum stalk respectively, phosphorus content varied from $0.03 \%$ to $0.76 \%$ and from $0.03 \%$ to $0.68 \%$. The highest phosphorus content was obtained at week 16 with the two crop residues. However, the phosphorus content at week 12 and at week 16 were similar statistically with rice straw and sorghum stalk, respectively.

The low content of carbon, nitrogen and phosphorus observed at the start in the substrate could be due to its exploitation by farmers through cultivation and tillage. In fact, producers cultivated the soil since years without any proper conservation practices. According to Liu et al. [32], soil cultivation and tillage can 
reduce its content in carbon and nitrogen, and therefore lead to its deterioration. The increase in soil organic carbon, nitrogen and phosphorus during the experiment could be linked to crop residues decomposition under microorganism's activity which consists of immobilization and mineralization [33]. Crop residues decomposition increases soil organic matter, which is a major terrestrial pool for plant nutrients, and consequently improves soil physical properties, conserving water, and increasing available nutrients [34]. Also, soil organic matter is not only an important source of carbon for soil processes but also a sink for carbon [32]. Crop residues are rich in nutrients and when they are incorporated into the soil, they constitute a form of organic restitution and therefore the first and best advance that enriches the soil before cultivation. Returning crop residues to soil, in contrast to its removal or burning, has been shown to increase the organic matter content of topsoil in many long-term field experiments [35] [36]. The findings of our experiment are in conformity to those of Azmal et al. [37] who observed an increase in soil chemical composition after incorporation of rice straw. Singh et al. [38] noted an important increase in organic matter, organic carbon, nitrogen, and phosphorus when incorporating rice and wheat crop residues in soil than burning them.

\subsubsection{C/N and C/P Ratios}

The $\mathrm{C} / \mathrm{N}$ ratio is frequently used as a quality index to evaluate the potential of crop residues in nutrients [39]. The carbon-nitrogen ratio during the decomposition of the various residues varied as a function of time (Table 2). Initially, the $\mathrm{C} / \mathrm{N}$ ratio was 12.16 in the substrate. Four weeks after the start of the experiment, $\mathrm{C} / \mathrm{N}$ ratio increased in the substrate with all the crop residues. With corn stalk, week 8 and 12 registered the highest $\mathrm{C} / \mathrm{N}$ ratios statistically. A significant decrease of $16.69 \%$ in $\mathrm{C} / \mathrm{N}$ ratio was observed at week 16 . The $\mathrm{C} / \mathrm{N}$ ratio ranged from 12.16 to 76.89 with millet straw, from 12.16 to 91.70 with rice straw and from 12.16 to 75.88 with sorghum stalk. The highest $\mathrm{C} / \mathrm{N}$ ratio was measured at week 16 with millet straw, at week 8 with rice straw and at week 12 with sorghum stalk. The increase in $\mathrm{C} / \mathrm{N}$ ratio during the decomposition of crop residues could be explained by the fact that these residues contained more carbon than nitrogen. Also, during the decomposition, less carbon was mineralized in the form of $\mathrm{CO}_{2}$ or assimilated by the soil microflora.

Table 2. Variation in $\mathrm{C} / \mathrm{N}$ ratio during crop residues decomposition.

\begin{tabular}{|c|c|c|c|c|c|}
\hline \multirow{2}{*}{$\begin{array}{l}\text { Type of crop } \\
\text { residues }\end{array}$} & \multicolumn{5}{|c|}{ Time (week) } \\
\hline & 0 & 4 & 8 & 12 & 16 \\
\hline Corn stalk & $12.16 \pm 0.87^{\mathrm{d}}$ & $44.58 \pm 5.72^{c}$ & $75.48 \pm 3.26^{\mathrm{a}}$ & $76.59 \pm 3.15^{\mathrm{a}}$ & $63.80 \pm 5.17^{b}$ \\
\hline Millet straw & $12.16 \pm 0.11^{c}$ & $63.46 \pm 11.53^{b}$ & $62.70 \pm 6.32^{\mathrm{b}}$ & $62.70 \pm 8.1^{b}$ & $76.89 \pm 2.81^{\mathrm{a}}$ \\
\hline Rice straw & $12.16 \pm 1.51^{\mathrm{d}}$ & $57.39 \pm 2.67^{\mathrm{a}}$ & $91.70 \pm 4.17^{\mathrm{a}}$ & $78.25 \pm 9.57^{\mathrm{b}}$ & $60.34 \pm 8.15^{\mathrm{c}}$ \\
\hline Sorghum stalk & $12.16 \pm 0.6^{\mathrm{c}}$ & $66.08 \pm 4.21^{\mathrm{b}}$ & $63.24 \pm 7.41^{\mathrm{b}}$ & $75.88 \pm 3.6^{\mathrm{a}}$ & $62.23 \pm 2.84^{\mathrm{b}}$ \\
\hline
\end{tabular}

Values followed by the same letter in a row are not significantly different $(\mathrm{p}>0.05)$ using LSD. 
The carbon-phosphorus ratio varied as a function of time, and type of crop residue during the decomposition (Table 3). At the start of the experiment, the $\mathrm{C} / \mathrm{P}$ ratio was 48.66 and it increased with all the crop wastes. The highest $\mathrm{C} / \mathrm{P}$ ratio was $62.94 \pm 12.03$ obtained at week 4 . With millet straw, rice straw and sorghum stalk, the highest $\mathrm{C} / \mathrm{P}$ ratio was $74.33 \pm 10.12$ got at week $12,88 \pm 4.72$ at week 4 , and $84.44 \pm 4.21$ at week 4 , respectively. The decrease in C/P ratio after the increase could explained microorganism's activity that accelerate the decomposition process and therefore liberate nutrient as phosphorus.

Table 3. Variation in $\mathrm{C} / \mathrm{P}$ ratio of substrate in function of crop wastes decomposition.

\begin{tabular}{cccccc}
\hline \multirow{2}{*}{$\begin{array}{c}\text { Type of crop } \\
\text { residue }\end{array}$} & $\mathbf{5}$ & \multicolumn{5}{c}{ Time (week) } \\
\cline { 2 - 6 } & $\mathbf{0}$ & $\mathbf{4}$ & $\mathbf{8}$ & 12 & 16 \\
\hline Corn stalk & $48.66 \pm 1.21^{\mathrm{b}}$ & $62.94 \pm 12.03^{\mathrm{a}}$ & $33.42 \pm 2.61^{\mathrm{b}}$ & $47.36 \pm 3.24^{\mathrm{b}}$ & $49.02 \pm 3.43^{\mathrm{b}}$ \\
Millet straw & $48.66 \pm 1.34^{\mathrm{b}}$ & $37.5 \pm 2.33^{\mathrm{c}}$ & $53.75 \pm 3.02^{\mathrm{b}}$ & $74.33 \pm 10.12^{\mathrm{a}}$ & $70.55 \pm 8.47^{\mathrm{a}}$ \\
& & & & & \\
Rice straw & $48.66 \pm 1.74^{\mathrm{c}}$ & $88 \pm 4.72^{\mathrm{a}}$ & $62.66 \pm 6.11^{\mathrm{b}}$ & $69.43 \pm 7.68^{\mathrm{b}}$ & $69.86 \pm 6.52^{\mathrm{b}}$ \\
& & & & & \\
Sorghum stalk & $48.66 \pm 1.02^{\mathrm{c}}$ & $84.44 \pm 4.21^{\mathrm{a}}$ & $40.34 \pm 8.24^{\mathrm{c}}$ & $60.46 \pm 6.94^{\mathrm{b}}$ & $61.32 \pm 7.11^{\mathrm{b}}$
\end{tabular}

Values followed by the same letter in a row are not significantly different $(p>0.05)$ using LSD.

\subsection{Correlation between Plant Nutrients in Crop Residues}

The relationships between the type of crop residues used in this study and their chemical characteristics were performed thanks to the principal component analysis (Figure 3).

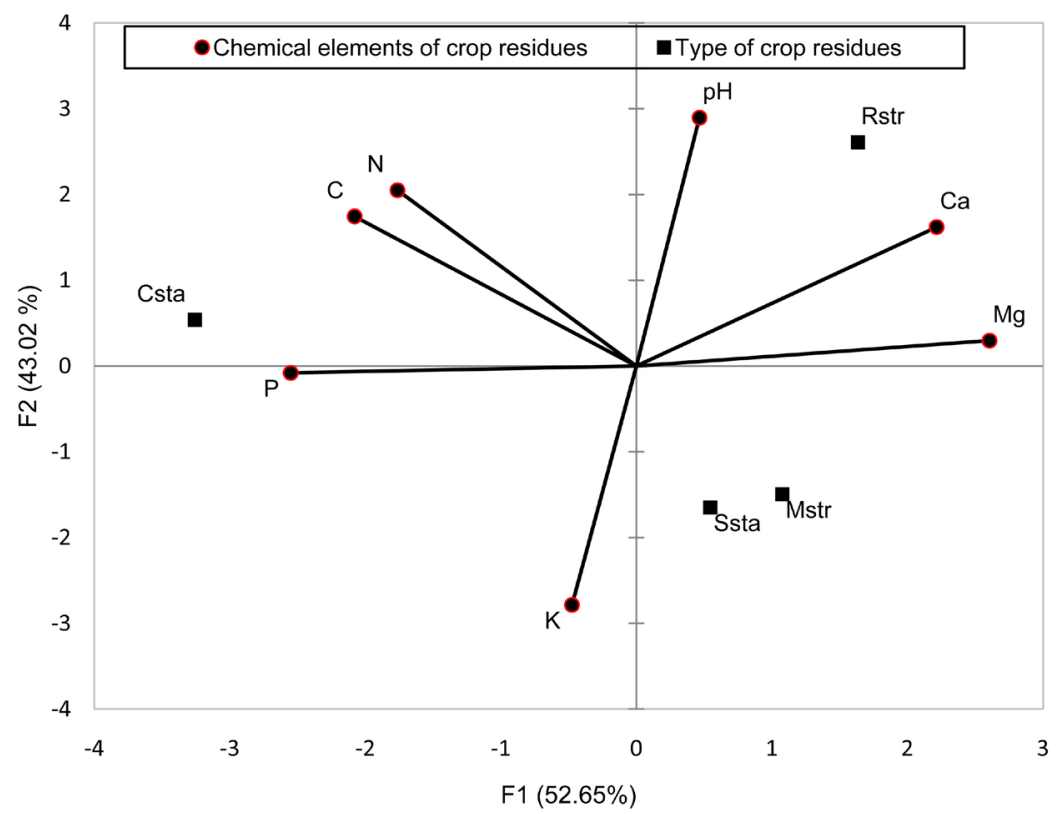

Figure 3. Correlation between cereal crop residues and chemical elements. Csta: corn stalk, Rstr: rice straw, Ssta: sorghum stalk, Mstr: millet straw, C: carbon, N: nitrogen, Ca: calcium, Mg: magnesium, $\mathrm{K}$ : potassium, $\mathrm{pH}$ : hydrogen potential. 
The principal component analysis revealed that the different type of crop residues differed by their chemical characteristics. Crop residues were clustered into three groups based on their chemical composition. Group 1 and group 2 were constituted of corn stalk and rice straw respectively when group 3 gathered millet straw and sorghum stalk. Also, it appeared that $\mathrm{C}$ and $\mathrm{N}$ were strongly correlated on one hand and $\mathrm{pH}, \mathrm{Ca}$, and $\mathrm{Mg}$ were correlated on the other hand. A correlation was suspected between $\mathrm{P}$ and $\mathrm{K}$. The three groups in crop residues in function of their chemical composition could be due to the cultivated area. In fact, in the north of Côte d'Ivoire, sorghum and millet are always cultivated side by side. The availability of the same nutrients for both plants might explain the similarity in their residue's chemical elements. The correlations between nutrients in this study agreed with the results of Ogidi et al. [40] when they were working on soil-plant nutrients.

\section{Conclusion}

This study demonstrated that corn stalk, millet straw, rice straw and sorghum stalk with higher $\mathrm{N}$, and $\mathrm{P}$ have a potential to supply higher amounts of $\mathrm{N}$ and $\mathrm{P}$ nutrients. Millet straw and rice straw could be beneficial for fast-growing and early planted crops. In contrast, corn stalk and sorghum stalk release nutrients slowly which would be beneficial for longer availability of the nutrients.

\section{Acknowledgements}

Authors wish to thank cereal crop producers to allow us to collect the residues in their farms. We are also grateful to the Laboratory of Chemical Analysis of National Petroleum Operations Company of Côte d'Ivoire. Thanks, should be given to the authorities of the University Peleforo Gon Coulibaly for their support during the experiment.

\section{Conflicts of Interest}

The authors declare no conflicts of interest regarding the publication of this paper.

\section{References}

[1] Brown, G.G., Edwards, C.A. and Brussaard, L. (2004) Soil Macrofauna in SE Mexican Pastures and the Effect of Conversion from Native to Introduced Pastures. Agriculture, Ecosystem and Environment, 103, 313-327. https://doi.org/10.1016/j.agee.2003.12.006

[2] Bhadauria, T. and Saxena, K.G. (2009) Role of Earthworms in Soil Fertility Maintenance through the Production of Biogenic Structures. Applied and Environmental Soil Science, 2010, Article ID: 816073. https://doi.org/10.1155/2010/816073

[3] Levêque, C.H. (1994) Environnement et Diversité du Vivant. Cité des Sciences et de l'Industrie, Paris, 128 p.

[4] Food and Agriculture Organization and Reducing Emissions from Deforestation and Forest Degradation (2017) Données Forestières de Base Pour la REDD+ en 
Côte d'Ivoire: Cartographie de la Dynamique Forestière de 1986 à 2015. Abidjan, 18 p.

[5] Food and Agriculture Organization of the United Nations (2011) Save \& Grow-A Policymakers Guide to the Sustainable Intensification of Smallholder Crop Production. Food and Agriculture Organization of the United Nations, Rome, 116.

[6] Louppe, D. and Ouattara, N'K. (2016) Etude sur l'Exploitation Forestière et les Contraintes d'une Gestion Durable des Forêts dans le Domaine Rural en Côte d'Ivoire. Deutsche Gesellschaft für Internationale Zusammenarbeit (GIZ) GmbH, Bonn, 67 p.

[7] He, M.M., Li, W.H., Liang, X.Q., Wu, D.L. and Tian, G.M. (2009) Effect of Composting Process on Phytotoxicity and Speciation of Copper, Zinc and Lead in Sewage Sludge and Swine Manure. Waste Management, 29, 590-597. https://doi.org/10.1016/j.wasman.2008.07.005

[8] Cambardella, C.A., Russell, A. and Richard, T.L. (2003) Compost Mineralization in Soil as a Function of Composting Process Conditions. European Journal of Soil Biology, 39, 117-127. https://doi.org/10.1016/S1164-5563(03)00027-X

[9] Erenstein, O. (2002) Crop Residue Mulching in Tropical and Semi-Tropical Countries: An Evaluation of Residue Availability and Other Technological Implications. Soil and Tillage Research, 67, 115-133. https://doi.org/10.1016/S0167-1987(02)00062-4

[10] Nottidge, D.O., Ojeniyi, S.O. and Asawalam, D.O. (2005) A Comparative Effect of Plant Residue and NPK Fertilizer on Nutrient Status and Yield of Maize in a Humid Ultisol. Nigerian Journal of Soil Science, 15, 1-8.

[11] Hegde, D.M. (1998) Effect of Integrated Nutrient Management on Productivity and Soil Fertility in Pearl Millet-Wheat Cropping System. Indian Journal of Agronomy, 43, 580-587.

[12] Deshmukh, M.R., Jain, H.C., Duhoon, S.S. and Goswami, U. (2002) Integrated Nutrient Management in Sesame Fir Kymore Plateau Zone of M.P. Journal of Oilseeds Research, 19, 73-75.

[13] Scagnozzi, A., Saviozzi, A., Levi-Minzi, R. and Riffaldi, R. (1997) Nutrient Release from Decomposing Crop Residues in Soil: A Laboratory Experiment. The American Journal of Alternative Agriculture, 12, 10-13. https://doi.org/10.1017/S0889189300007116

[14] Bauder, J. (2000) Decomposition Rate of Cereal Straw as Affected by Soil Placement. Cereal Crop Residues and Plant Nutrients, Montana State University Communications Services.

[15] Campbell, C.A., Janzen, H.H., Paustian, K., Greegorich, E.G., Sherrod, L., Liang, B.C. and Zentner, R.P. (2005): Carbon Storage in Soils of the North American Great Plains: Effect of Cropping Frequency. Agronomy Journal, 97, 349-363. https://doi.org/10.2134/agronj2005.0349

[16] Dagnogo, F., Coulibaly, S.S., Konaté, D, and Fofana, L., (2018) Low Productivity of Onion in Côte d'Ivoire: Causes and Recommendations. International Journal of Agriculture \& Environmental Science, 5, 49-56. https://doi.org/10.14445/23942568/IJAES-V5I5P108

[17] Borowik, A. and Wyszkowska, J. (2016) Soil Moisture as a Factor Affecting the Microbiological and Biochemical Activity of Soil. Plant, Soil and Environment, 62, 250-255. https://doi.org/10.17221/158/2016-PSE

[18] Fosu, M., Kuhne, R.F. and Vlek, P.L. (2007) Mineralization and Microbial Biomass 
Dynamics during Decomposition of Four Leguminous Residues. Journal of Biological Sciences, 7, 632-637. https://dx.doi.org/10.3923/jbs.2007.632.637

[19] Ferraz, G.P., Frear, C., Pelaez-Samaniego, M.R., Englund, K. and Garcia-Perez, M. (2016) Hot Water Extraction of Anaerobic Digested Dairy Fiber for Wood Plastic Composite Manufacturing. BioResources, 11, 8139-8154. https://doi.org/10.15376/biores.11.4.8139-8154

[20] Xie, J.X., Li, Y., Zhai, C.X., Li, C.H. and Lan, Z.D. (2009) $\mathrm{CO}_{2}$ Absorption by Alkaline Soils and Its Implication to the Global Carbon Cycle. Environmental Geology, 56, 953-961. https://doi.org/10.1007/s00254-008-1197-0

[21] Anguria, P., Chemining'wa, G.N., Richard, N., Onwonga, R.N. and Ugen, M.A. (2017) Decomposition and Nutrient Release of Selected Cereal and Legume Crop Residues. Journal of Agricultural Science, 9, 108-119. https://doi.org/10.5539/jas.v9n6p108

[22] Hoorman, J.J. (2010) Understanding Soil Microbes and Nutrient Recycling: SAG-16, Agriculture and Natural Resources. Ohio State University, Ohio.

[23] Cattanio, J.H., Kuehne, R. and Vlek, P.L.G. (2008) Organic Material Decomposition and Nutrient Dynamics in a Mulch System Enriched with Leguminous Trees in the Amazon. Revista Brasileira de Ciência do Solo, 32, 1073-1086. https://doi.org/10.1590/S0100-06832008000300016

[24] Baggie, I., Rowell, D.L, Robinson, J.S. and Warren, G.P. (2005) Decomposition and Phosphorus Release from Organic Residues as Affected by Residue Quality and Added Inorganic Phosphorus. Agroforestry System, 63, 125-131.

https://doi.org/10.1007/s10457-004-5131-5

[25] Yan, F., Schubert, S. and Mengel, K. (1996) Soil pH Increase Due to Biological Decarboxylation of Organic Anions. Soil Biology and Biochemistry, 28, 617-624. https://doi.org/10.1016/0038-0717(95)00180-8

[26] Ritchie, G.S.P. and Dolling, P.J. (1985) The Role of Organic Matter in Soil Acidification. Australian Journal of Soil Research, 23, 569-576. https://doi.org/10.1071/SR9850569

[27] Helyar, K.R. and Porter, W.M. (1989) Soil Acidification, Its Measurements and the Processes Involved. In: Robson, A.D., Ed., Soil Acidity and Plant Growth, Academic Press, Sydney, 61-101. https://doi.org/10.1016/B978-0-12-590655-5.50007-4

[28] Hoyt, P.B. and Turner, R.C. (1975) Effects of Organic Materials Added to Very Acid Soils on pH, Aluminum, Exchangeable NH4, and Crop Yields. Soil Science, 119, 227-237. https://doi.org/10.1097/00010694-197503000-00008

[29] Bessho, T. and Bell, L.C. (1992) Soil and Solution Phase Changes and Mung Bean Response during Amelioration of Aluminium Toxicity with Organic Matter. Plant Soil, 140, 183-196. https://doi.org/10.1007/BF00010596

[30] Pocknee, S. and Sumner, M.E. (1997) Cation and Nitrogen Contents of Organic Matter Determine Its Soil Liming Potential. Soil Science Society of America Journal, 61, 86-92. https://doi.org/10.2136/sssaj1997.03615995006100010014x

[31] Tang, C. and Yu, Q. (1999) Impact of Chemical Composition of Legume Residues and Initial Soil $\mathrm{pH}$ on $\mathrm{pH}$ Change of a Soil after Residue Incorporation Plant and Soil, 215, 29-38. https://doi.org/10.1023/A:1004704018912

[32] Liu, X., Herbert, S.J., Hashemi, A.M., Zhang, X. and Ding, G. (2006) Effects of Agricultural Management on Soil Organic Matter and Carbon Transformation. Plant Soil and Environment, 52, 531-543. https://doi.org/10.17221/3544-PSE

[33] Feichtinger, F., Erhart, E. and Hartl, W. (2004) Net N-Mineralization Related to Soil 
Organic Matter Pools. Plant Soil and Environment, 50, 273-276.

https://doi.org/10.17221/4032-PSE

[34] Onemli, F. (2004) The Effects of Soil Organic Matter on Seedling Emergence in Sunflower (Helianthus annuus L.). Plant Soil and Environment, 50, 494-499. https://doi.org/10.17221/4064-PSE

[35] Alvarez, R. (2005) A Review of Nitrogen Fertilizer and Conservation Tillage Effects on Soil Organic Carbon Storage. Soil Use and Management, 21, 38-52. https://doi.org/10.1111/j.1475-2743.2005.tb00105.x

[36] Chan, K.Y., Heenan, D.P. and So, H.B. (2003) Sequestration of Carbon and Changes in Soil Quality under Conservation Tillage on Light-Textured Soils in Australia: A Review. Australian Journal of Experimental Agriculture, 43, 325-334. https://doi.org/10.1071/EA02077

[37] Azmal, A.K.M., Marumoto, T., Shindo, H. and Nishiyama, M. (1997) Changes in Microbial Biomass after Continuous Application of Azolla and Rice Straw in Soil. Soil Science and Plant Nutrition, 43, 811-818. https://doi.org/10.1080/00380768.1997.10414647

[38] Singh, R.K., Sharma, G.K., Kumar, P., Singh, S.K. and Singh, R. (2019) Effect of Crop Residues Management on Soil Properties and Crop Productivity of Rice-Wheat System in Inceptisols of Seemanchal Region of Bihar. Current Journal of Applied Science and Technology, 37, 1-6. https://doi.org/10.9734/cjast/2019/v37i630324

[39] Cortez, J., Garnier, E., Perez-Haguindeguy, N., Debussche, M. and Gillon, D. (2007) Plant traits, Litter Quality, and Decomposition in a Mediterranean Oldfield Succession. Plant and Soil, 296, 19-34. https://doi.org/10.1007/s11104-007-9285-6

[40] Ogidi, E.G.O., Okore, I.K. and Dike, J.C. (2018) Correlation Analysis of Nutrient Soil-Plant Content and Bud Take Success in Hevea. Journal of Experimental Biology and Agriculture Science, 6, 116-123. https://doi.org/10.18006/2018.6(1).116.123 